\title{
Antibacterial, Antifungal and Antibiofilm Activity of Methylglyoxal: A Phytochemical from Manuka Honey
}

\author{
Metilglioksalın Antibakteriyel, Antifungal ve Antibiyofilm Aktivitesi: Manuka Balından Bir \\ Fitokimyasal
}

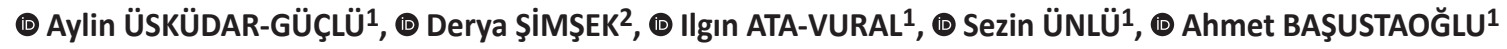 \\ 1 Başkent University Faculty of Medicine, Department of Medical Microbiology, Ankara, Turkey \\ 2Başkent University Faculty of Medicine, Ankara, Turkey
}

\section{Abstract}

Introduction: Honey has been known for its ability to promote wound healing for a long time. It is utilized for several skin and soft tissue infections caused by a wide range of microorganisms due to its antimicrobial property. Methylglyoxal (MGO), the unique antibacterial compound contained by Manuka honey, is believed as the reason for the antimicrobial activity of Manuka honey. This study aims to identify the antibacterial, antifungal and anti-adherent activity of MGO in changing concentrations and determine the viable number of bacteria and fungi in biofilm after the treatment of MGO.

Materials and Methods: Antibacterial and antifungal activity of MGO was determined by broth microdilution method for identifying minimum inhibitory and bactericidal and fungicidal concentrations (MIC, MBC and MFC, respectively). Percentage of biofilm formation inhibition and the number of viable microorganisms in biofilm after the MGO treatment was determined by the colony-forming unit method.

Results: Minimum inhibitory concentration values for the bacterial strains ranged from 0.0078 to $0.125 \%$ ( $/ \mathrm{v}$ ), while MBC ranged from 0.0312 to $2 \%(\mathrm{v} / \mathrm{v})$. Among fungi, MIC and MFC values were higher than those for tested bacterial strains; MIC values ranged from 0.0156 to $1 \%$ (v/v), while MFC values ranged from 0.0625 to $2 \%(\mathrm{v} / \mathrm{v})$. Methylglyoxal was able to prevent biofilm formation in the all tested biofilm forming isolates. Number of viable bacteria, even in the sub-inhibitory doses of MGO, reduced remarkably.

Conclusion: Unique compound of Manuka honey, MGO, exerts significant antimicrobial and antibiofilm activity against clinically important strains of both bacteria and fungi which may be utilized for the search of promising alternatives for antibiotics and may lead to combat antibiotic resistance.

Keywords: Methylglyoxal, antibacterial, antifungal, antibiofilm

\section{Öz}

Giriş: Balın yara iyileşmesi üzerine etkisi uzun süredir bilinmektedir. Antimikrobiyal özelliğinden dolayı çeşitli mikroorganizmaların neden olduğu çeşitli deri ve yumuşak doku enfeksiyonlarında baldan yararlanılmaktadır. Manuka balının antimikrobiyal aktivitesinin sebebinin eşsiz bir antibakteriyel bileşik olan metilglioksal (MGO) içermesinden kaynaklandığı düşünülmektedir. Bu çalışma, MGO'nun değisşen konsantrasyonlarda antibakteriyel, antifungal ve anti-biyofilm aktivitesini belirlemeyi ve MGO uygulamasından sonra biyofilmdeki canlı bakteri ve mantar sayısını belirlemeyi amaçlamaktadır.

Gereç ve Yöntem: Metilglioksalın, minimum inhibisyon konsantrasyonu, minimum bakterisidal ve fungisidal konsantrasyonları (MiK, MBC ve MFC, sırasıyla) sıvı mikrodilüsyon yöntemi ile belirlenerek antifungal ve antibakteriyel etkinliği araştırılmıştır. Metilglioksalın mikroorganizmaların biyofilm oluşturmalarını engelleme yüzdeleri ve biyofilmdeki canlı mikroorganizma sayısı koloni oluşturan birim yöntemi ile belirlenmiştir.

Bulgular: Bakteri suşları için MiK değerleri \%0,0078 ile 0,125 (v/v) arasında değişirken, MBC \%0,0312 ile 2 (v/v) arasında değişmektedir. Mantarlar arasında, MiK ve MFC değerleri, test edilen bakteri suşları için olanlardan daha yüksektir; MiK değerleri \%0,0156 ile 1 (v/v) arasında değişirken, MFC değerleri \%0,0625 ile 2 (v/v) arasında bulunmuştur. Metilglioksalın, test edilen tüm biyofilm oluşturan izolatlarda biyofilm oluşumunu engelleyebildiği saptanmıştır. Metilglioksalın sub-inhibitör dozlarında da canlı bakteri sayısını önemli ölçüde azalttığı belirlenmiştir.

Cite this article as: Üsküdar-Güçlü A, Şimşek D, Ata-Vural I, Ünlü S, Başustaoğlu A. Antibacterial, Antifungal and Antibiofilm Activity of Methylglyoxal: A Phytochemical from Manuka Honey. Mediterr J Infect Microb Antimicrob. 2021;10:55. 


\section{Öz}

Sonuç: Manuka balının eşsiz bileşiği olan MGO'nun, hem bakteri hem de mantarların klinik olarak önemli suşlarına karşı antimikrobiyal ve antibiyofilm aktivite göstermiş olması, MGO'nun antibiyotiklere karşı umut verici bir alternatif olarak kullanılabileceğini ve antibiyotik direnciyle mücadeleye yardımcı olabileceğini gösterebilmektedir.

Anahtar Kelimeler: Metilglioksal, antibakteriyel, antifungal, antibiyofilm

\section{Introduction}

Many important human pathogens causing various types of infections have been acquired resistance to antibiotics, leading to consumption of the last resorts of antibiotics. One of the major reasons of antibiotic resistance is over-usage of antibiotics. Besides, biofilm formation can also provide an advantage to microorganisms to develop antibiotic resistance and complicate the treatment ${ }^{[1]}$. Therefore, the requirement of new, more natural compound as alternative therapeutics against pathogenic microorganisms is aroused. Many researches are being focused on alternative approaches to treat multidrugresistant and/or biofilm forming microorganisms.

Honey was found to have several benefits as an alternative medicine, such as wound healing and as an anticancer agent and it is stimulant for tissue generation, inflammation reduction and antimicrobial properties. Mainly, the antimicrobial activity of honey has come from low $\mathrm{pH}$ since several types of them contain hydrogen peroxide, which helps to dehydrate microorganisms. On the other hand, Manuka honey is monofloral honey derived from the Manuka tree and has been recently researched for its high level of antimicrobial activity which is mainly aroused from its unique compound, methylglyoxal $(\mathrm{MGO})^{[2]}$. Manuka honey contains an unusually high level of MGO formed from dihydroxyacetone which correlates with its significant antimicrobial activity. Unique Manuka Factor (UMF) is a classification used for rating Manuka honey. The UMF value refers to the MGO content of the honey, and it is suggested that this is responsible for much of the honey's antibacterial properties $^{[3]}$. When the UMF of Manuka honey is above 10, Manuka is used for therapeutics reasons ${ }^{[4]}$. It was found that Manuka honey had higher antibacterial activity against microorganisms, with a stronger UMF.

Beside the antimicrobial activities, medically important Manuka honey has in vitro antibiofilm activity ${ }^{[5,6]}$, and MGO's antibiofilm activity was demonstrated against several microorganisms such as $P$. aeruginosa, $S$. aureus and methicillin-resistant $S$. aureus $^{[7]}$. The strong antibiofilm activity of Manuka honey is provided by its phenol component, MGO. The addition of extra MGO into Manuka honey increased the antibiofilm activity of Manuka honey ${ }^{[8,9]}$. Since there is no much studies showing the antibacterial, antifungal and antibiofilm activity of MGO against medically important microorganisms, this study aimed to evaluate in vitro antibacterial, antifungal and anti-adherent activities of MGO against medically important pathogens and also its effects on biofilm viability.

\section{Materials and Methods}

This study was approved Başkent University Institutional Review Board (project no: KA21/156).

\section{Bacterial Strains}

Standard strains used in this study were as follows: S. aureus ATCC 29213, S. aureus ATCC 6538, S. epidermidis ATCC 12228, E. faecalis ATCC 29212, S. pyogenes ATCC 19615, E. coli ATCC 25922, K. pneumoniae ATCC 700603, A. baumannii ATCC 19606, P. aeruginosa ATCC 27853, P. aeruginosa ATCC 15442, Candida albicans ATCC 10231, C. krusei ATCC 6258, C. guilliermondii ATCC 6260, and C. parapsilosis ATCC 22019.

\section{Methylglyoxal}

Methylglyoxal solution ( $40 \% \mathrm{w} / \mathrm{vol}$ in water, Sigma Aldrich) was diluted in $\mathrm{dH}_{2} \mathrm{O}$. Concentrations of $\mathrm{MGO}$ were ranged from $0.0039 \%(\mathrm{v} / \mathrm{v})$ to $2 \%(\mathrm{v} / \mathrm{v})$.

\section{Antibacterial Activity of Methylglyoxal}

The antibacterial activity of MGO is determined by broth microdilution method in 96-well plates for determining minimum inhibitory concentration (MIC), and instructions in Clinical and Laboratory Standards Institute was followed ${ }^{[10]}$. Methylglyoxal was diluted twofold in Mueller-Hinton Broth (MHB) (BD Difco ${ }^{T M}$, France) $)^{[11]}$. Each well was inoculated with 100 $\mu \mathrm{l}$ of bacterial suspension and $100 \mu \mathrm{l}$ of different concentrations of $\mathrm{MGO}$, ranging from $0.0039 \%(\mathrm{v} / \mathrm{v})$ to $2 \%(\mathrm{v} / \mathrm{v})$. The wells without MGO solution containing solely bacterial suspension in $\mathrm{MHB}$ were used as growth controls, while wells containing sterile MHB without bacterial suspension or MGO were used as sterility controls. The wells were incubated for $24 \mathrm{~h}$ at $37^{\circ} \mathrm{C}$. Each experiment was performed in triplicate.

Minimum bactericidal concentration (MBC) protocol was applied with slight modifications ${ }^{[11]} ; 10 \mu \mathrm{l}$ of bacterial suspension from each well containing different doses of MGO were inoculated on Tryptic Soy Agar (TSA) (BD Difco ${ }^{\mathrm{TM}}$, France) and sheep blood 
agar (Orbak, Turkey). After $24 \mathrm{~h}$ of incubation at $37{ }^{\circ} \mathrm{C}, \mathrm{MBC}$ was determined as the lowest concentration in which no microbial growth was observed.

\section{Antifungal Activity of Methylglyoxal}

Antifungal activity of MGO to standard strains including C. albicans ATCC 10231, C. krusei ATCC 6258, C. parapsilosis ATCC 22019 and C. guilliermondii ATCC 6260 were tested by following EUCAST standards ${ }^{[12]}$. Candida species were cultured on Sabouraud Dekstroz Agar (SDA) (BD Difco ${ }^{\mathrm{TM}}$, France) at 35 ${ }^{\circ} \mathrm{C}$. The RPMI (Sigma-Aldrich, Germany) medium were prepared according to EUCAST standards for broth dilution, and MGO was diluted two-fold serially. The $100 \mu \mathrm{l}$ of inoculation were added to wells, and after $24 \mathrm{~h}$ of incubation, MIC was defined as the lowest concentration of the MGO inhibiting growth of fungi at the desired concentration. The $10 \mu \mathrm{l}$ of fungal suspension from each well were inoculated on SDA. After $24 \mathrm{~h}$ of incubation at $35^{\circ} \mathrm{C}, \mathrm{MBC}$ was determined as the lowest concentration in which no microbial growth was observed.

\section{Biofilm Formation Assay}

The method defined by Shirlaw et al. ${ }^{[13]}$ was used for biofilm formation. Flat-bottom polystyrene microtiter plates containing $180 \mu \mathrm{l}$ of Tryptic Soy Broth (TSB) (Condalab, Spain) were inoculated with $20 \mu \mathrm{l}$ of bacterial culture calibrated to $1 \times 10^{6} \mathrm{CFU} /$ $\mathrm{ml}$. Biofilm formation was quantified by the crystal violet (CV) staining method after the incubation period. The supernatant was removed, and the wells were washed three times with 200 $\mu \mathrm{l}$ phosphate saline buffer (PBS, pH 7.2). The biofilms were fixed by adding $200 \mu \mathrm{l}$ 95\% methanol into each well for 20 minutes, and then the supernatant was removed. Then, $0.2 \% \mathrm{CV}$ solution was added to each well, and 20 min later, the excess dye was removed by washing with PBS three times, and then wells were air-dried. Lastly, $200 \mu$ l of $95 \%$ ethanol was added to wells, followed by incubation for $10 \mathrm{~min}$ at room temperature. The absorbance was measured at $570 \mathrm{~nm}$ (BioTek Instruments, ELX 800, USA), and strains were evaluated as negative, weak, intermediate and strong biofilm former ${ }^{[14]}$. While $S$. aureus ATCC 6538 and P. aeruginosa ATCC 15442 were used as positive controls, S. aureus ATCC 29213 and P. aeruginosa ATCC 27853 were used as negative controls for biofilm formation.

Calculation of Biofilm Formation Inhibition Percentage of Methylglyoxal

To find the effects of MGO on biofilm formation, biofilmforming isolates were selected and tested according to their ability to form biofilm in the presence of MGO. The effect of MGO against tested biofilm-forming isolates and control strains were detected in 96-well plates. Briefly, $100 \mu$ of bacterial suspension for each isolate was added to each well containing different doses of MGO ranging from $0.0039 \%(\mathrm{v} / \mathrm{v})$ to $2 \%(\mathrm{v} / \mathrm{v})$. After 24 $\mathrm{h}$ of incubation, a biofilm staining procedure was applied, and $O D$ values were quantified. Wells without MGO was used as a control to calculate the percentage of biofilm inhibition in wells with different MGO concentration as follows ${ }^{[15]}$.

Percentage of inhibition $=[($ Control OD570 nm - Sample OD570 nm) / Control OD570 nm] x 100

\section{Effects of Methylglyoxal on Biofilm Viability}

Biofilm viability assay was performed on well biofilm forming strains including S. aureus ATCC 6538, P. aeruginosa ATCC 15442 and C. albicans ATCC 10231 by previously defined method with slight modifications ${ }^{[16]}$. Wells with preformed biofilm were washed twice with saline solution. $200 \mu \mathrm{l}$ of MGO solution with different concentrations was added to each well. The sonication procedure was applied for 10 seconds and 30\% amplitude (Daihan, Korea). After the sonication process, wells were scrapped to remove excessive biomass. To quantify the viable microorganism in biofilm, the serially diluted suspension from each well were plated and after the 24 hours of incubation, colonies were counted. The values were compared with the viable number of microorganisms in wells without MGO.

\section{Biofilm Viability in Sub-inhibitory Doses of Methylglyoxal}

Inoculation of biofilm-forming strains was prepared in TSB and RPMI for bacteria and Candida spp. respectively and incubated for 24 hours in 96-well plates. After the 24 hours, wells were washed with PBS and filled with $200 \mu$ l broth containing MIC $1 / 2,1 / 4,1 / 8$ and 1/16 of MGO. After 24 hours of incubation, homogeneous suspensions were obtained from biofilm by sonication method, and wells were scrapped. The serially diluted suspension from each well were plated on TSA for bacteria and SDA for Candida spp. After 24 hours of incubation, colonies were counted.

\section{Statistical Analysis}

No statistical analysis was conducted in this study and hence, that is not provided.

\section{Results}

Antibacterial and Antifungal Effects of Methylglyoxal

A total of 10 different standard bacterial strains ( 5 Gram-negative and 5 Gram-positive) were included the study. Among them, MIC values ranged from 0.0078 to $0.125 \%(\mathrm{v} / \mathrm{v})$, while $\mathrm{MBC}$ ranged from 0.0312 to $2 \%$ (v/v) (Table 1). Most susceptible microorganisms to $\mathrm{MGO}$ was found as $S$. pyogenes with the $0.0078 \%(\mathrm{v} / \mathrm{v})$ of MIC and $0.0312 \%(\mathrm{v} / \mathrm{v})$ of MBC, followed by $S$. aureus with the second-lowest MIC and MBC values. P. aeruginosa was the less susceptible strain to MGO as seen in Table 1.

Among fungi, four different strains of Candida spp. were included. Minimum inhibitory concentration and MFC values 
were higher than those for tested bacterial strains; MIC values ranged from 0.0156 to $1 \%(\mathrm{v} / \mathrm{v})$, while MFC values ranged from 0.0625 to $2 \%(\mathrm{v} / \mathrm{v})$. C. albicans ATCC 10231 was found to most susceptible to MGO, while $C$. guilliermondii ATCC 6260 was the most resistant strain (Table 1).

\section{Biofilm Formation Inhibition Percentage of Methylglyoxal}

Biofilm formation inhibition ranges were from $92 \%$ to $1 \%$. Methylglyoxal at concentrations ranging from 0.0156 to $2 \%(\mathrm{v} / \mathrm{v})$ were able to inhibit biofilm formation in all tested isolates. Biofilm formation was inhibited at $92 \%$ at a MGO concentration of 1\% (v/v) in A. baumannii ATCC 19606 which is medium biofilm forming bacteria. In concentrations lower than $0.0156 \%(v / v)$, no biofilm inhibitory activity was detected (Figure 1a). Biofilm formation was also significantly inhibited in the presence of MGO ranging from 0.0312 to $1 \%(\mathrm{v} / \mathrm{v})$ in $S$. aureus ATCC 6538 (Figure 1b) which is a strong biofilm forming bacteria. However, biofilm formation was inhibited solely in higher concentration for C. albicans ATCC 10231 and decreased sharply as the concentration decreased (Figure 1c). Biofilm formation of $P$. aeruginosa ATCC 15442 was also inhibited by $\mathrm{MGO}$ only in concentrations ranging from 0.0625 to $2 \%(\mathrm{v} / \mathrm{v})$; below this concentration there was nearly no biofilm inhibitory activity (Figure 1d).

\section{Effects of Methylglyoxal on Biofilm Viability}

Total viable bacterial and fungal count were determined after the sonication process and 24 hours of incubation of the isolates of S. aureus ATCC 6538, P. aeruginosa ATCC 15442 and C. albicans ATCC 10231 separately in solely broth (without MGO) and broth with different concentrations of MGO (Figure

Table 1. MIC, MBC and MFC values of standard strains

\begin{tabular}{l|l|l}
\hline Standard strains & $\begin{array}{l}\text { MIC } \\
(\% \mathrm{v} / v)\end{array}$ & $\begin{array}{l}\text { MBC/MFC } \\
(\% \mathrm{v} / \mathrm{v})\end{array}$ \\
\hline S. aureus ATCC 29213 & 0.0156 & 0.0312 \\
\hline S. aureus ATCC 6538 & 0.0156 & 0.0312 \\
\hline S. epidermidis ATCC 12228 & 0.0312 & 0.125 \\
\hline E. faecalis ATCC 29212 & 0.0312 & 0.0625 \\
\hline S. pyogenes ATCC 19615 & 0.0078 & 0.0312 \\
\hline E. coli ATCC 25922 & 0.0312 & 0.0625 \\
\hline K. pneumoniae ATCC 700603 & 0.0625 & 0.0625 \\
\hline A. baumannii ATCC19606 & 0.0312 & 0.0312 \\
\hline P. aeruginosa ATCC 27853 & 0.0312 & 2 \\
\hline P. aeruginosa ATCC 15442 & 0.125 & 0.125 \\
\hline C. albicans ATCC 10231 & 0.0156 & 0.0625 \\
\hline C. krusei ATCC 6258 & 1 & 1 \\
\hline C. guilliermondii ATCC 6260 & 1 & 2 \\
\hline C. parapsilosis ATCC 22019 & 0.25 & 2 \\
\hline
\end{tabular}

MIC: Minimum inhibitory concentration, MBC: Minimum bactericidal concentration, MFC: Minimum fungicidal concentration
2). The number of viable bacteria and fungi in broth without $\mathrm{MGO}$ and even in the lowest concentration of MGO $[0.0078 \%$ $(\mathrm{v} / \mathrm{v})]$ was differed remarkably for each of the tested isolate. At a highest concentration of $\mathrm{MGO}$, viable cell in biofilm was the lowest for each tested species.

\section{Biofilm Viability in Sub-inhibitory Doses of Methylglyoxal}

Number of viable cell in sub-inhibitory doses of MGO was tested against S. aureus ATCC 6538 and C. albicans ATCC 10231. Number of viable bacteria and fungi in MGO concentration at MIC $1 / 2,1 / 4,1 / 8$ and $1 / 16$ of these isolates were determined (Figure 3). It was found that even in MGO concentration at MIC $1 / 8$, number of viable bacteria in biofilm was remarkably lower than wells without MGO treatment.

\section{Discussion}

Multidrug resistance bacteria causing infections pose severe challenges, which led to the need for alternative antimicrobial agents, especially for those with the ability to form biofilm. Since the antimicrobial mechanisms of Manuka honey are different from those of conventional antimicrobial agents, it can be a promising alternative against multidrug-resistant bacterial and fungal isolates and biofilm forming microorganisms ${ }^{[2]}$. It was demonstrated that Manuka honey contains a significantly high number of phenolic compounds responsible for its antimicrobial property. Even though hydrogen peroxide $\left(\mathrm{H}_{2} \mathrm{O}_{2}\right)$ contributes antimicrobial activity of several types of honey due to low $\mathrm{pH}$, the high concentration of the unique compound of Manuka honey, MGO, is thought to reason behind this antimicrobial activity ${ }^{[17]}$

It was demonstrated earlier that increased concentration of Manuka honey exerts increased antimicrobial property since increment in osmotic pressure disruption, leakage of cellular materials, floral origin and phytochemical component ${ }^{[18]}$. As expected, decreased antimicrobial activity of MGO on lower dilutions was demonstrated in this study.

In this study, MGO activity against medically important Grampositive and negative bacteria, as well as Candida species were tested. Our results are concordant with previously published researches. Kilty et al. ${ }^{[7]}$ was reported similar results that highlighted MGO's efficacy against $P$. aeruginosa and $S$. aureus, including MRSA biofilms. Our results showed that MGO is less effective against fungi including $C$. albicans, $C$. krusei $C$. parapsilosis and C. guilliermondii than bacterial strains, which is in agreement with previously published studies ${ }^{[11]}$.

Our study showed that biofilm formation was inhibited significantly, especially in higher concentrations of MGO. At a concentration from 1 to $0.0625 \%(\mathrm{v} / \mathrm{v})$, biofilm formation was significantly inhibited in the medium biofilm former 


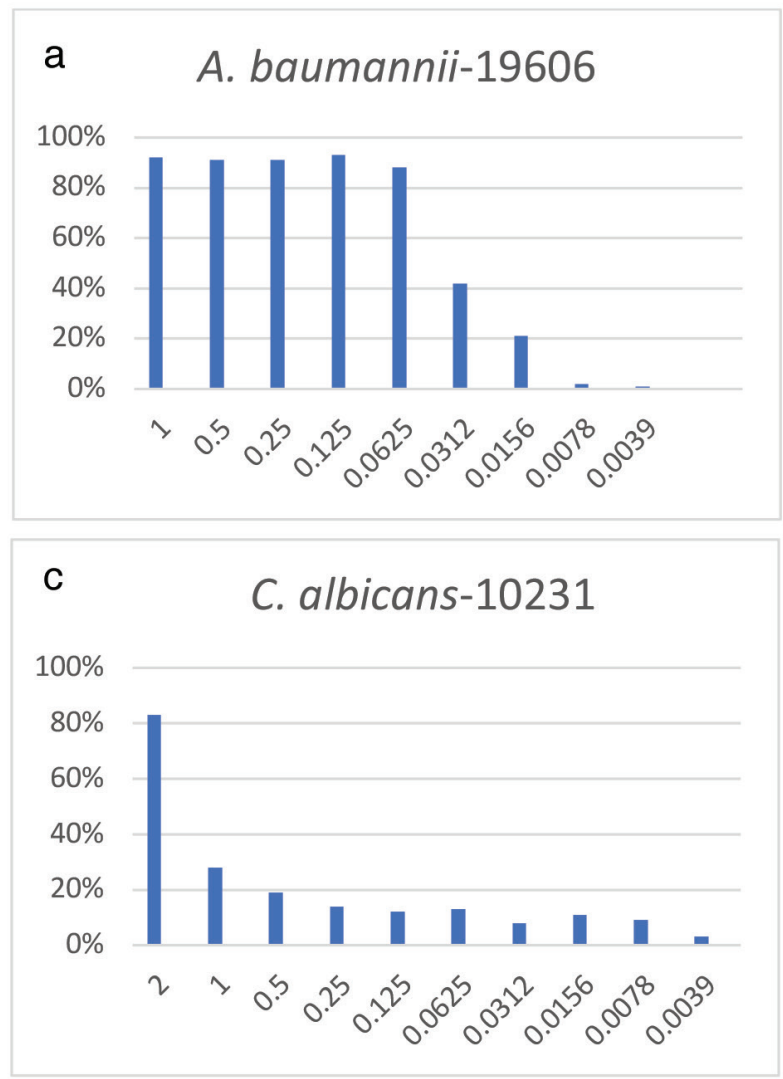

b

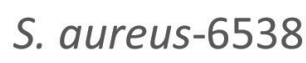

$100 \%$

$80 \%$

$60 \%$

$40 \%$

$20 \%$

$0 \%$

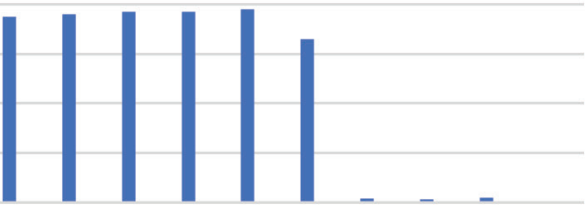

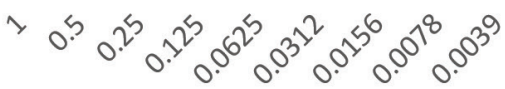

d

\section{P. aeruginosa-15442}

$100 \%$

$80 \%$

$60 \%$

$40 \%$

$20 \%$

$0 \%$

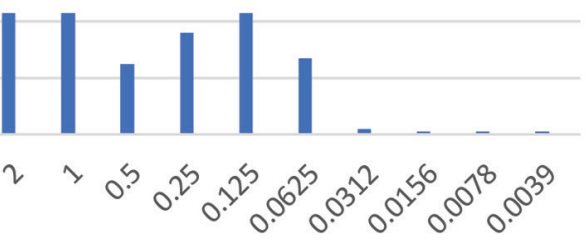

Figure 1. Biofilm formation inhibition percentages of a) A. baumannii 19606, b) S. aureus 6538, c) C. albicans ATCC 10231 and d) $P$. aeruginosa ATCC 15442 in dose-dependent manner

strain A. baumannii ATCC 19606. At a MGO concentration $0.0312 \%(\mathrm{v} / \mathrm{v})$, inhibition of biofilm formation decreased sharply, this may be due to the fact that $0.0312 \%(\mathrm{v} / \mathrm{v})$ was found to MIC value of this isolate. Same results were also obtained from the experiment on S. aureus ATCC 6538 and C. albicans ATCC 10231. Biofilm formation was prevented significantly until the MIC concentrations of these isolates. Lu et al. ${ }^{[19]}$ suggested that reduction of biofilm formation may be induced by stress response similar to antibiotics, and MGO's mechanisms of action were by killing bacteria trapped in biofilm ${ }^{[3]}$.

It is known that biofilm formation provides barrier to restricts the penetration of antibiotics into the biofilm and diffusion of some antibiotics into the biofilm is low. Therefore, it is expected and advantageous that agents with an antimicrobial activity will also be effective in the biofilm. For these reasons, a promising agent, MGO's activity against biofilm viability was also tested in this study. Biofilm viability is evaluated by sonication method since it is advantageous to allow enumerate viable bacteria in biofilm over conventional methods such as colorimetric methods. Therefore, due to the limitation of enumerating viable or total bacteria in biofilm in those methods, biofilm quantification was evaluated by the CFU counting method ${ }^{[16,20]}$.

Number of viable bacteria in biofilm was quantified and found that even in the lowest concentrations of MGO, number of viable bacteria reduced significantly in comparison with the untreated wells. Even in the sub-inhibitory concentrations of MGO, it shows great activity and able to reduce viable bacteria. As expected, increased number of viable bacteria in biofilm on dilutions was demonstrated.

Our study has a limitation that further in vivo and in vitro analysis need to be conducted before presenting MGO as an alternative therapeutics.

\section{Conclusion}

In conclusion, antifungal and anti-adherent activity of MGO against medically important pathogens and also its effects on biofilm viability were demonstrated. Methylglyoxal revealed strong antimicrobial and anti-adherent activity in in vitro setting. Its activity within the biofilm, even in the sub-inhibitory concentrations may provide promising alternatives against biofilm forming multidrug-resistant bacterial and fungal isolates. 

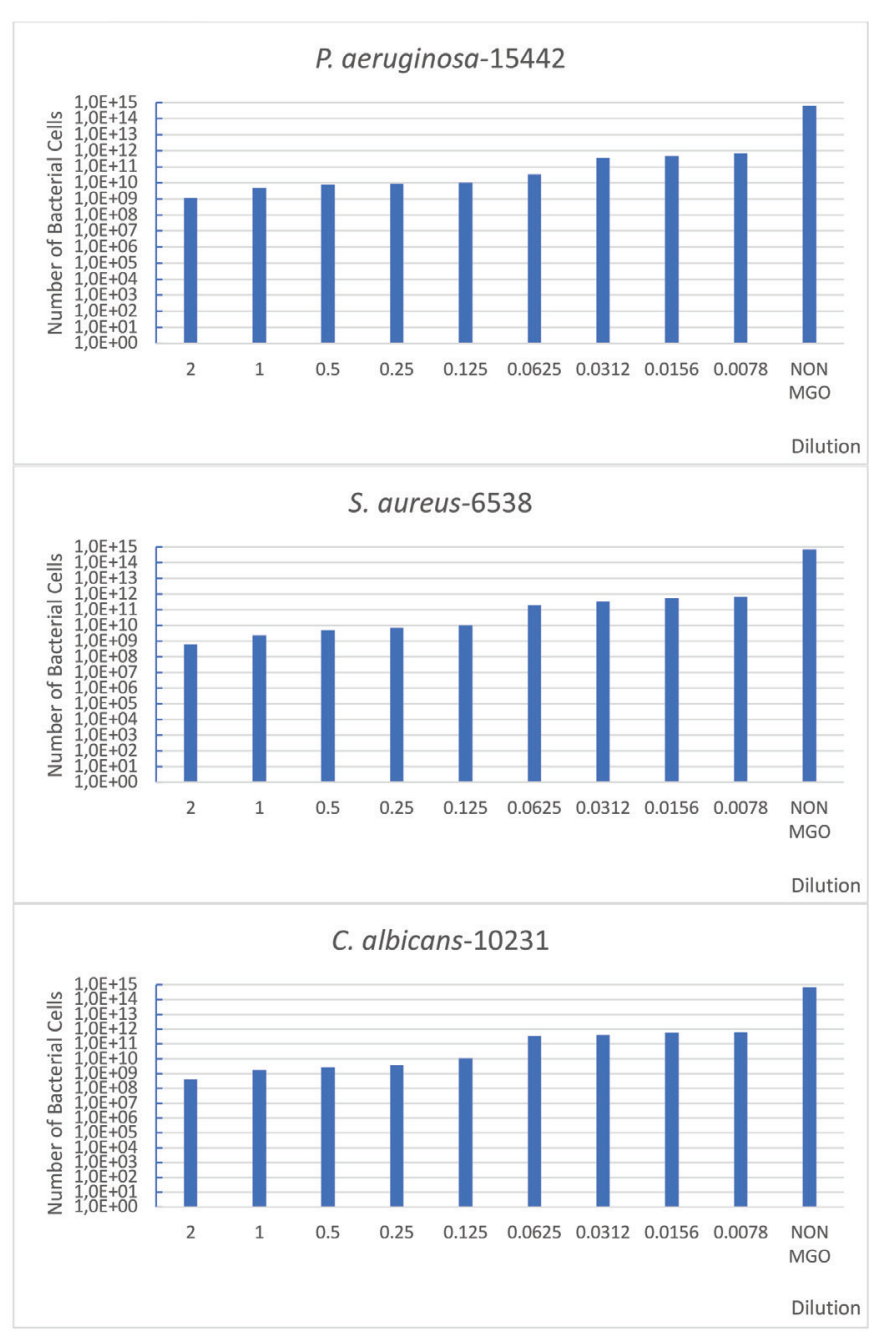

Figure 2. Quantitative results were obtained by CFU method. Number of viable bacteria and fungi in biofilm; after the treatment with and without methylglyoxal

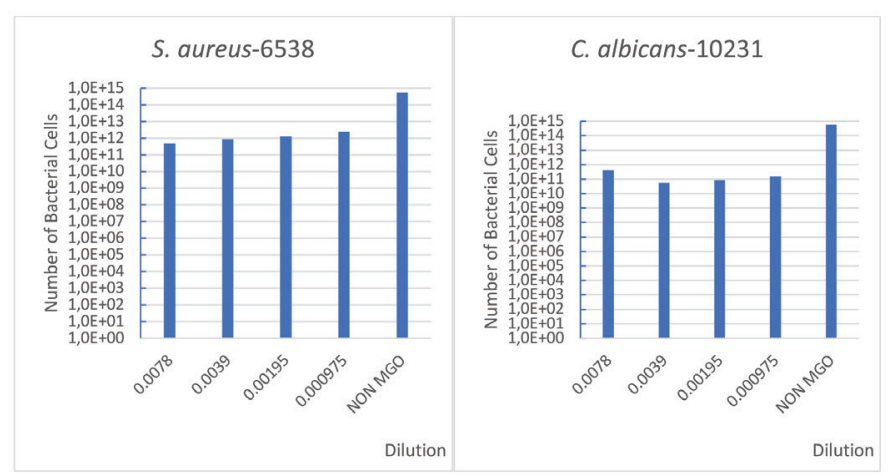

Figure 3. Number of viable bacteria and fungi in methylglyoxal concentration at minimum inhibitory concentration $1 / 2,1 / 4,1 / 8$ and $1 / 16$

\section{Ethics}

Ethics Committee Approval: This study was approved by Başkent University Institutional Review Board (Project no: KA 21/156). There is no need for ethical approval since the study includes standard bacterial strains.

Informed Consent: There were no patients attended to the study.

Peer-review: Externally peer-reviewed.

\section{Authorship Contributions}

Concept: A.Ü.G., Design: A.Ü.G., A.B., S.Ü., Data Collection or Processing: D.Ş., I.A.V., Analysis or Interpretation: A.Ü.G., S.Ü., A.B., D.Ş., Literature Search: S.Ü., I.A.V., D.Ş., A.B., Writing: A.Ü.G., S.Ü., I.A.V.

Conflict of Interest: No conflict of interest was declared by the authors.

Financial Disclosure: This study was supported by Başkent University Research Fund.

\section{References}

1. Boles BR, Thoendel M, Roth AJ, Horswill AR. Identification of genes involved in polysaccharide-independent Staphylococcus aureus biofilm formation. PLoS One. 2010;5:e10146.

2. Girma $A$, Seo W, She RC. Antibacterial activity of varying UMF-graded Manuka honeys. PLoS One. 2019;14:e0224495.

3. Johnston $M$, McBride $M$, Dahiya $D$, Owusu-Apenten $R$, Nigam PS Antibacterial activity of Manuka honey and its components: An overview. AIMS Microbiol. 2018;4:655-64.

4. Rabie E, Serem JC, Oberholzer HM, Gaspar AR, Bester MJ. How methylglyoxal kills bacteria: An ultrastructural study. Ultrastruct Pathol. 2016;40:107-11.

5. Maddocks SE, Jenkins RE, Rowlands RS, Purdy KJ, Cooper RA. Manuka honey inhibits adhesion and invasion of medically important wound bacteria in vitro. Future Microbiol. 2013;8:1523-36.

6. Campeau ME, Patel R. Antibiofilm Activity of Manuka Honey in Combination with Antibiotics. Int J Bacteriol. 2014;2014:795281.

7. Kilty SJ, Duval M, Chan FT, Ferris W, Slinger R. Methylglyoxal: (active agent of manuka honey) in vitro activity against bacterial biofilms. Int Forum Allergy Rhinol. 2011;1:348-50.

8. Paramasivan S, Drilling AJ, Jardeleza C, Jervis-Bardy J, Vreugde $\mathrm{S}$, Wormald PJ. Methylglyoxal-augmented manuka honey as a topical antiStaphylococcus aureus biofilm agent: safety and efficacy in an in vivo model. Int Forum Allergy Rhinol. 2014;4:187-95.

9. Jervis-Bardy J, Foreman A, Bray S, Tan L, Wormald PJ. Methylglyoxal-infused honey mimics the anti-Staphylococcus aureus biofilm activity of manuka honey: potential implication in chronic rhinosinusitis. Laryngoscope. 2011:121:1104-7.

10. Abmm D, Tamma D, Kirn J, Cullen SK, Clinical and Laboratory Standards Institute (CLSI). Performance Standards for Antimicrobial Susceptibility Testing. $30^{\text {th }}$ ed. CLSI Supplement M100. 2020; Wayne, PA. Available from: https://www.nih.org.pk/wp-content/uploads/2021/02/CLSI-2020.pdf

11. Juliano C, Magrini GA. Methylglyoxal, the major antibacterial factor in manuka honey: an alternative to preserve natural cosmetics? Cosmetics. 2019;6:1. 
12. Rodríguez-Tudela JL, Barchiesi F, Bille J, Chryssanthou E, Cuenca-Estrella M, Denning D, Donnelly JP, Dupont B, Fegeler W, Moore C, Richardson M, Verweij $P E$. Method for the determination of minimum inhibitory concentration (MIC) by broth dilution of fermentative yeasts. CMI. 2003;98:i-viii.

13. Shirlaw O, Billah Z, Attar B, Hughes L, Qasaymeh RM, Seidel V, Efthimiou G. Antibiofilm Activity of Heather and Manuka Honeys and Antivirulence Potential of Some of Their Constituents on the DsbA1 Enzyme of Pseudomonas aeruginosa. Antibiotics (Basel). 2020;9:911.

14. Sayin Z, Ucan US, Sakmanoglu A. Antibacterial and Antibiofilm Effects of Boron on Different Bacteria. Biol Trace Elem Res. 2016;173:241-6.

15. Balaji K, Thenmozhi R, Pandian SK. Effect of subinhibitory concentrations of fluoroquinolones on biofilm production by clinical isolates of Streptococcus pyogenes. Indian J Med Res. 2013;137:963-71.

16. Freitas $\mathrm{Al}$, Vasconcelos $\mathrm{C}$, Vilanova $\mathrm{M}$, Cerca N. Optimization of an automatic counting system for the quantification of Staphylococcus epidermidis cells in biofilms. J Basic Microbiol. 2014;54:750-7.
17. Almasaudi SB, Al-Nahari AAM, Abd El-Ghany ESM, Barbour E, Al Muhayawi SM, Al-Jaouni S, Azhar E, Qari M, Qari YA, Harakeh S. Antimicrobial effect of different types of honey on Staphylococcus aureus. Saudi J Biol Sci. 2017;24:1255-61.

18. Kumar ND, Kalluru RS, Ahmed S, Abhilashini A, Jayaprakash T, Garlapati $R$, Sowmya B, Reddy KN. Comparison of the Antibacterial Efficacy of Manuka Honey Against E. faecalis and E. coli - An In vitro Study. J Clin Diagn Res. 2014;8:ZC29-31.

19. Lu J, Turnbull L, Burke CM, Liu M, Carter DA, Schlothauer RC, Whitchurch $\mathrm{CB}$, Harry EJ. Manuka-type honeys can eradicate biofilms produced by Staphylococcus aureus strains with different biofilm-forming abilities. PeerJ. 2014;2:e326.

20. Hannig C, Follo M, Hellwig E, Al-Ahmad A. Visualization of adherent microorganisms using different techniques. J Med Microbiol. 2010;59:1-7. 